\title{
FACTORS DETERMINING THE PURCHASE OF INSURANCE PRODUCTS
}

\author{
Anna Jańska \\ Maria Curie-Sklodowska University, Lublin, Poland \\ e-mail: anna.janska@umcs.pl \\ ORCID: 0000-0002-5994-8061

\section{Arleta Kędra} \\ Maria Curie-Sklodowska University, Lublin, Poland \\ e-mail: arleta.kedra@umcs.pl
}

ORCID: 0000-0002-5867-3078

(C) 2019 Anna Jańska, Arleta Kędra

This is an open access article distributed under the Creative Commons Attribution-NonCommercial-NoDerivs license (http://creativecommons.org/licenses/by-nc-nd/3.0/)

DOI: 10.15611/eada.2019.1.02

JEL Classification: C01, A10, C58, C59, G00

\begin{abstract}
This paper centres to the presentation of analyzed potential relations between the determinants of purchasing decisions regarding insurance products and socio-demographic variables, i.e. age, gender, place of residence, income, occupational status, and number of people in the household. The authors also examined whether making financial decisions in a household determines purchasing decisions concerning insurance products. The main hypothesis is: from the perspective of an elderly customer, inherent features of an analyzed insurance product are more vital than aspects regarding the sales process. The analysis was conducted using the ordered logit model, where factors determining purchases of insurance products were used as dependent variables.
\end{abstract}

Keywords: insurance, ordered logit model, customers' preferences, purchase decisions.

\section{Introduction}

Customers' preferences concerning affordable and flexible solutions in insurance are a key driver in the insurance sector. The effective implementation of new insurance products is possible only after gaining a thorough knowledge about customers, for example by determining their expectations and rationale behind their choices. Due to the ageing of the society, the question arises whether popular, currently functioning insurance products are adequate to the needs of the elderly. Therefore, considerations regarding the rationale behind their purchasing decisions when choosing an insurer 
or a particular insurance product are justified. What is more crucial, the inherent features of a given insurance, such as the insurer's liability, the insured sum, or the quality of the offered process i.e. the sales process, the ongoing policy's service, or the loss adjustment? What is the key determinant when choosing the insurer - their reputation, tradition and history or the attributes concerning innovation and the novelty effect?

The aim of the research was to determine the correlation between the determinants of the choice of an insurance product, which were expressed as ordinal categorical variables, and socio-demographic variables, i.e. age, gender, place of residence, income, occupational status and the number of members in the household. The main research hypothesis is: from the perspective of an older person the inherent features of a given insurance product are more significant than the factors connected with the sales process.

\section{Material and methods}

The above mentioned relationships were determined using ordered logit models, where the dependent variables were insurance choice determinants and the regressors - socio-demographic variables. Source data were taken from a survey, conducted by a team of the Maria-Curie Skłodowska University consisting of staff and students. The subjects of the survey were the people born before 1967.

The first step of the research involved presenting the features and structure of the collected data. Therefore, the authors presented summary statistics (mean, median, standard deviation, coefficient of variation, and skewness) for the analyzed variables representing the determinants of insurance purchasing decisions. The next step of the research regarded estimating ordered logit models in which the insurance choice determinants were used as the dependent variables and their changes were explained by the socio-economic variables, used as independent variables. Logit models belong to a group of models used when the dependent variable is limited (categorical variable), i.e. it takes values from a limited number of possible values (it is a discrete variable) [Greene 2012]. Ordered logit models are constructed for ordinal variables, i.e. discrete variables that have values which can be logically ranked or ordered (e.g. from the worst to the best). Logit models enable finding statistically significant factors of the examined phenomenon and examining the effects of interactions between those factors, and are used for explaining qualitative dependent variables by the changes of regressors (quantitative or qualitative). These can be used for modeling risk or clients' loyalty [Jackowska 2011]. 


\section{Theoretical basis}

Even the primary research of the literature suggests that aspects of purchasing decisions on the insurance market in the case of an insurance and of an insurer occur frequently in the scientific literature concerning insurance awareness [Walczak, Majewski 2013] and are connected with identifying the quality of insurance services [Garczarczyk 2003]. The research on the individual customers, within the scope of the discussed issue, was concerned with, among others, the preferences and motives of choice of the life insurer [Nowotarska-Romaniak 2015] and the factors determining the choice of an insurer [Wicka, Miedzik 2010]. According to the analysis by B. Czerwiński [2015], choosing the given insurance services by people of over 50 is determined by the socio-demographic variables: income and occupancy, and variables connected with insurance determinants: price, availability of the services and conditions of a given insurance. As the author states, the correlation between determinants such as gender and the place of residence, and variables concerning insurance services was not statistically significant enough. In English-speaking literature the research results are connected directly with the segmentation of insurers' clients and determining their preferences and patterns of behavior on the insurance market among differentiated customers groups such as the elderly [Moschis, Friend 2008].

Their perspective differs significantly from that of the overall population, notably from the point of view of young people. The reason behind this is that the elderly have more experience, often also a higher financial status, and have a distinct risk perception. Due to the progressing demographic changes, both in Poland and in the whole European Union, this topic is considered to be prevailing and crucial, from the perspective of the insurance sector and of the whole society. One may state that there is a research gap and this research aims at filling this gap.

\section{Research results and discussion}

The paper presents the results of a survey conducted by a staff from the Maria CurieSklodowska University's Faculty of Economics in cooperation with the students. The survey was conducted among 388 participants, all born before 1967. The structure of the subjects was analyzed in terms of their answers to the questions asked. The main area of interest was the correlation between the preferred factors determining the purchase of insurance and socio-demographic variables, i.e. gender, age, place of residence, and the subjective evaluation of their financial situation. Due to the fact that some observations were missing, the answers of five respondents were eliminated.

The next step of the research was to analyze carefully aspects which determine the choice of insurance product. These aspects were expressed literally in the survey questionnaire, where the subjects were to assess each determinant subjectively. 
Table 1. Structure of the respondents

\begin{tabular}{|l|l|r|r|}
\hline \multicolumn{1}{|c|}{ Variable } & \multicolumn{1}{c|}{ Value } & Number & Percentage share \\
\hline Gender & Female & 231 & $60.31 \%$ \\
\hline & Male & 152 & $39.69 \%$ \\
\hline Age & $50-55$ & 95 & $24.80 \%$ \\
\hline & $56-65$ & 147 & $38.38 \%$ \\
\hline & $66-74$ & 86 & $22.45 \%$ \\
\hline & $75+$ & 55 & $14.36 \%$ \\
\hline Occupational status & Employed & 199 & $51.96 \%$ \\
\hline & Unemployed & 15 & $3.92 \%$ \\
\hline & Retired & 152 & $39.69 \%$ \\
\hline & Pensioner & 31 & $8.09 \%$ \\
\hline
\end{tabular}

Source: own calculation on the basis of the survey.

Those polled had to use a five-level Likert scale, where value 1 was assigned to the response "not important" and value 5 to the response "very important". Summary statistics, i.e. mean, median, standard deviation, the coefficient of variation, and skewness were calculated for each determinant, with the usage of Data Analysis and Statistical Software: Stata. The results are presented in Table 2.

Table 2. Summary statistics for the determinants of purchasing an insurance product

\begin{tabular}{|l|r|r|r|r|r|}
\hline \multicolumn{1}{|c|}{ Determinant } & Mean & Median & $\begin{array}{c}\text { Standard } \\
\text { deviation }\end{array}$ & $\begin{array}{c}\text { Coefficient } \\
\text { of variation }\end{array}$ & Skewness \\
\hline Scope of insurance & $\mathbf{4 . 2 3 3}$ & 5.00 & 1.08 & 0.26 & -1.54 \\
\hline Insurance premium & $\mathbf{4 . 2 3 0}$ & 5.00 & 1.04 & 0.25 & -1.58 \\
\hline Previous experience & 3.97 & 4.00 & 1.16 & 0.29 & -1.13 \\
\hline Quality of loss adjustment process & 3.87 & 4.00 & 1.25 & 0.32 & -1.01 \\
\hline Proximity of insurer's branch & 3.57 & 4.00 & 1.29 & 0.36 & -0.63 \\
\hline $\begin{array}{l}\text { Direct contact with the insurance } \\
\text { intermediary (broker, agent) }\end{array}$ & 3.47 & 4.00 & 1.24 & 0.36 & -0.51 \\
\hline Family's or friends' recommendation & 3.40 & 3.00 & 1.21 & 0.35 & -0.40 \\
\hline Promotion, special offers & 2.99 & 3.00 & 1.35 & 0.45 & -0.03 \\
\hline $\begin{array}{l}\text { Intermediary's recommendation } \\
\text { (agent's, broker's) }\end{array}$ & 2.88 & 3.00 & 1.40 & 0.49 & 0.57 \\
\hline Advertisement & 2.35 & 2.00 & 1.26 & 0.54 & 0.58 \\
\hline
\end{tabular}

Source: as in Table 1.

The data presented in Table 2 show that the most crucial factor, declared by the subjects, is the scope of insurance: this factor has a mean equal to 4.233 in the 1-5 scale. A slightly lower (only by 0.003 ) average is observed for the insurance premium. It is worth mentioning that both these factors have a median equal to 5 , which means 
that half of the questioned indicated them as very important (value 5). In both cases, distribution is left-skewed, which means that that the majority of the polled declared a level higher than the average. The lowest values were noted for advertisement - the average evaluation equals 2.35 , with a median equal to 2 . Half of the subjects regarded advertisement as not very important (value 2 or 1), declaring that they are relatively resistant to it. Distribution is right-skewed which indicates that the majority of respondents marked advertisement as less important than average. The distribution of evaluations is presented in Figure 1. The authors verified how many of those questioned declared each mark for each determinant, then this number was divided by the total number of those polled. Thus the relative values (percentage contribution values) were calculated.

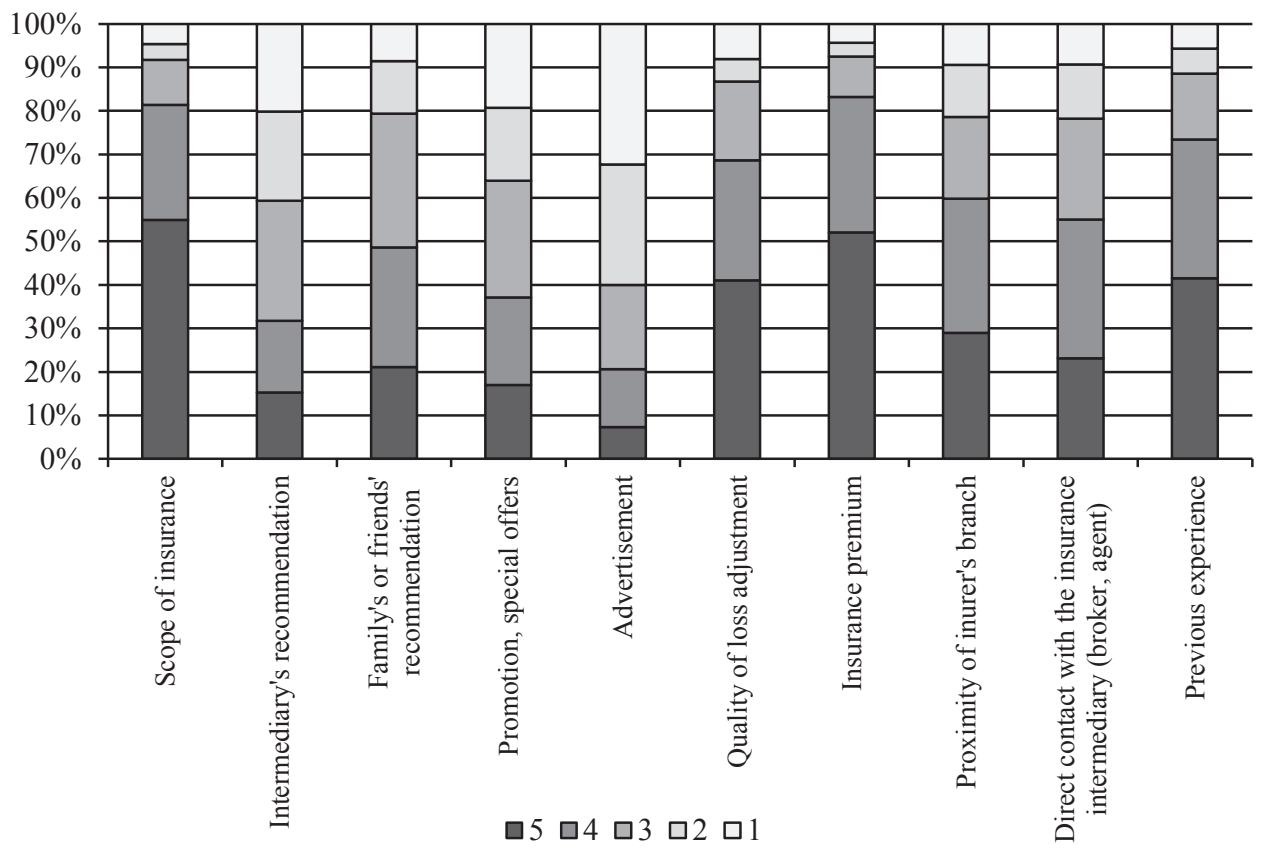

Fig. 1. Percentage contribution values of particular marks of determinants

Source: own calculation on the basis of the survey.

Taking into consideration the previously presented data, i.e. the significance of each factor, further analysis involved verifying revenues disposable of the questioned. The results are presented in Figure 2.

The above presented data show that the majority of the polled live in households where monthly incomes vary from PLN 1000 to 2000 (32.22\% of all the subjects) and from PLN 3001 to 4000 (28.61\% of all the subjects). To compare, the average gross monthly remuneration in Poland in 2016 was PLN 4290.52, and the average 


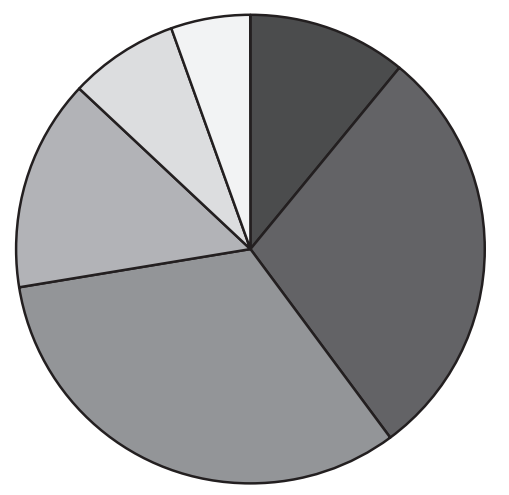

$\begin{array}{ll}\square \text { Less than1000 PLN } & \square 3001-4000 \text { PLN } \\ \square 1000-2000 \text { PLN } & \square 4001-5000 \text { PLN } \\ \square 2001-3000 \text { PLN } & \square \text { More than 5000 PLN }\end{array}$

Fig. 2. Percentage contribution values of particular marks of determinants

Source: as in Fig. 1.

monthly pension in Poland in 2016 was PLN 2086.35 [Bank Danych Lokalnych GUS]. It is worth mentioning that $10.82 \%$ of the respondents declared a monthly income of less than PLN 1000.

The results of the conducted research show unambiguously that the elderly who make decisions regarding the purchase of an insurance product focus on the features of this product, which is proved by the highest significance given to the scope of insurance. The second most crucial factor is the insurance premium. Previous experience in contact with insurers appeared to be relatively vital. Location factors, i.e. the proximity of the insurer's branch or direct contact with the insurance intermediary appeared to be considerably less significant. Taking this into consideration, one may arrive at the assumption that sales processes involving, for instance, internet sales channel is gaining greater importance. Factors connected with the sales process, i.e. promotion and special offers, the intermediary's recommendation, and advertisement were the least crucial ones. The elderly make their purchasing decisions on the basis of the inherent features of an insurance product.

The second stage of the research included constructing logit models for ordinal categorical variables, using 383 observations for which full answers were collected (the authors found the missing answers for five observations). The Programs Stata and Gretl were used to construct the models. Originally, all the socio-demographic variables were used as dependent variables; then those variables that seemed to be insignificant at the $10 \%$ significance level were eliminated. When eliminating insignificant variables, the p-value was used. The thus created models included only significant variables. Cut-points are considered to be only auxiliary parameters 
(according to the Stata Manual) and therefore are not interpreted. The results are presented in the table below.

Table 3. Coefficients and p-value in the constructed ordered logit models

\begin{tabular}{|l|l|l|}
\hline \multicolumn{1}{|c|}{ Dependent variable } & \multicolumn{1}{|c|}{ Explanatory variables } & p-value \\
\hline Direct contact with the insurance intermediary (broker, agent) & 0,41 Big city & 0.04 \\
\hline Proximity of insurer's branch & $-0,66$ Finance & 0.03 \\
\hline Quality of loss adjustment process & $-1,29$ Unemployed $^{\mathrm{a}}$ & 0.01 \\
\cline { 2 - 3 } & 0,32 Income & 0.07 \\
\hline \multirow{3}{*}{ Scope of insurance } & 0,04 Age & 0.01 \\
\cline { 2 - 3 } & 0,42 Big city & 0.08 \\
\cline { 2 - 3 } & $-0,05$ Employed & 0.08 \\
\cline { 2 - 3 } & $-1,96$ Unemployed & 0.001 \\
\cline { 2 - 3 } & 0,54 Income & 0.001 \\
\hline Promotion, special offers & $-0,37$ Retired & 0.05 \\
\hline Advertisement & 0,78 Pensioner & 0.019 \\
\hline Insurance premium & $-1,16$ Unemployed & 0.01 \\
\hline Intermediary's recommendation (agent's, broker's) & 0,47 Big city & 0.02 \\
\cline { 2 - 3 } & $-0,34$ Retired & 0.08 \\
\hline Family's or friends' recommendation & $-0,37$ Employed & 0.06 \\
\cline { 2 - 3 } & $-0,94$ Unemployed & 0.07 \\
\cline { 2 - 3 } & $+0,51$ Finance & 0.08 \\
\cline { 2 - 3 } & $-0,27$ Income & 0.05 \\
\hline
\end{tabular}

a -dummy variable, equaling 1 if a person decides about financial issues in their household;

$\mathrm{b}-$ to ease interpretation of the coefficients, log for income is used.

Source: as in Tables 1 and 2 .

The data presented in Table 3 show that only a few variables were statistically significant and were used as explanatory variables in the models. Gender, living in a small city and the number of people living in a household appeared to be statistically insignificant. Other variables were significant at a differentiated significance level $(1 \%, 5 \%$ or $10 \%)$. The next stage of the research included constructing models for limited dependent variables, i.e. ordered categorical variables. The interpretation of these models is based on analyzing the probability of choosing the "better" or "higher" options from the proposed ones.

The model where direct contact with the insurance intermediary was used as a dependent variable, included only one explanatory variable - living in a big city. People who live in a city with more than 200,000 inhabitants declare that direct contact with the insurance intermediary is 0.41 more important for them than for others. This variable is significant at the 5\% significance level. The proximity of the insurer's branch is determined by the dummy variable regarding financial decisions. 
Those polled who make these decisions in their households indicate the importance of the proximity of the insurer's branch as 0.66 higher than those who in these cases are dependent on other family members.

The declared relevance of the quality of the loss adjustment process is determined by the income and occupational status of those questioned. The unemployed believe that the importance of this determinant is 1.29 higher than the employed, whereas an increase of the income by $1 \%$ causes an increase of declared significance of this factor by 0.32 .

The research results show that the scope of insurance is differentiated in terms of the age of the respondents - people from each subsequent age range regard this determinant as 0.04 more crucial than those from a lower age range. Analyzing location factors, one may assume that people who live in cities with more than 200,000 inhabitants believe that the scope of insurance is 0.42 more vital than inhabitants of smaller cities. The unemployed declare that the scope of insurance is 1.96 less important, whereas the employed only by 0.05 . An income increase by $1 \%$ causes an increase of the declared relevance of this determinant by 0.54 .

Considering the aspects of the sales process, it is worth mentioning that the attitude of the retired is much more varied than of others. They think that the significance of promotion and special offers is 0.37 lower than of the others questioned. The pensioners declare that advertisement is 0.78 more important for them than for other respondents.

The importance of the intermediary's recommendation is determined by the place of residence - people who live in big cities state that this is 0.47 more important, and by the fact of being retired - this factor is 0.34 less crucial than others. Those employed declare the lower importance of family's and friends' recommendation by 0.34 , whereas the unemployed by 0.94 . Making financial decisions in a household causes an increase of declared importance by 0.51 . An income increase by $1 \%$ causes a decrease of 0.27 .

The results of the presented paper may be compared with those by B. Czerwiński [2015]. In his research based on the correlation matrix, the correlation between age and accessibility of insurance products via the internet and the questioned persons' disposable financial assets was proven. The correlation between other variables and age seemed to be insignificant, which is concurrent with the results of this paper. In the cited article, the author proves a correlation between the income of the subjects and the insurance price, which is incongruent with the results of the research conducted for this paper. The only explanatory variable in the model with insurance premium as the dependent variable was the dummy variable, showing whether the polled person is unemployed (at the 5\% significance level).

The results indicate the legitimacy of further analysis in this field, concerning real behavior of clients on the insurance market, which may be different from that declared. Further analysis of the correlation between the determinants of purchasing an insurance product and variables regarding location accessibility is recommended. 


\section{Conclusion}

The results of the research confirm the hypothesis that from the perspective of an older client, the inherent features of an insurance product are more relevant than factors regarding the sales process (loss adjustment services, contact with the insurer's intermediary, etc.). The correlation between determinants of the choice of an insurance product expressed as categorical variables, and socio-demographic variables was proven within the second stage of the research. For those polled, i.e. people born before 1967, such aspects as gender, living in a small city, and the number of members of a household appeared to be statistically insignificant. Age was an explanatory variable only in one model - where the scope of insurance was the dependent variable (at the $1 \%$ significance level).

It is worth mentioning that the present paper does not exhaust research assets within the factors determining the choice of an insurance product by the elderly. Further analyses of the correlation between the determinants of purchasing an insurance product and socio-demographic variables will enable a thorough study of the examined issue. It would be interesting to analyze research to verify discrepancies between determinants declared by the subjects and their real behavior on the insurance market.

\section{Bibliography}

Bank Danych Lokalnych GUS, https://bdl.stat.gov.pl/BDL/dane/podgrup/tablica (access: 07.03.2018). Czerwiński B., 2015, Determinanty zakupu ustug ubezpieczeniowych przez osoby powyżej 50. roku życia, Zeszyty Naukowe Uniwersytetu Szczecińskiego, Problemy Zarządzania, Finansów i Marketingu, $\mathrm{nr} 41(875)$, t. 2, pp. 50-59.

Garczarczyk J., 2003, Jakość ustugi ubezpieczeniowej jako przestanka zarzadzania zakładem ubezpieczeń, Gazeta Ubezpieczeniowa, http://www.gu.com.pl/index.php?option=com_content\&view=art icle \&id=6456\&catid=129:rynek-ubezpieczeniowy\&Itemid=151.

Greene W.H., 2012, Econometric Analysis, International Edition, Pearson Education Limited, Edinburgh, pp. 801-806.

Jackowska B., 2011, Efekty interakcji między zmiennymi objaśniającymi w modelu logitowym w analizie zróżnicowania ryzyka zgonu, Przegląd Statystyczny, nr 1-2, pp. 24-41.

Moschis G.P., Friend S.B., 2008, Segmenting the preferences and usage patterns of the mature consumer healthcare market, International Journal of Pharmaceutical and Healthcare Marketing, vol. 2, issue: 1, pp. 7-21.

Nowotarska-Romaniak B., 2015, Preferencje i motywy wyboru zakładu ubezpieczeń na życie przez klientów indywidualnych, Zeszyty Naukowe Uniwersytetu Szczecińskiego Problemy Zarządzania, Finansów i Marketingu nr 38(865), Uniwersytet Ekonomiczny w Katowicach, pp. 263-271.

Walczak D., Majewski P., 2013, Świadomość ubezpieczeniowa studentów w aspekcie postrzegania rynku ubezpieczeniowego, Studia Oeconomica Posnaniensia, vol. 1, no. 11(260), pp. 42-50.

Wicka A., Miedzik A., 2010, Rodzaje ubezpieczeń i czynniki decydujące o wyborze ubezpieczyciela, Zeszyty Naukowe Polityki Europejskie, Finanse i Marketing, nr 4(53), pp. 264-277. 


\section{CZYNNIKI DETERMINUJĄCE ZAKUP PRODUKTÓW UBEZPIECZENIOWYCH}

Streszczenie: W artykule zaprezentowano wyniki badań, których celem było przeanalizowanie potencjalnych zależności pomiędzy determinantami wyboru produktu ubezpieczeniowego, które wyrażono jako politomiczne zmienne jakościowe, a zmiennymi społeczno-demograficznymi, tj. wiekiem, płcią, miejscem zamieszkania, uzyskiwanym dochodem, statusem na rynku pracy oraz liczbą osób w gospodarstwie domowym. Zweryfikowano również, czy decydowanie o kwestiach finansowych w gospodarstwie domowym wpływa na podejmowane decyzje zakupowe w zakresie produktów ubezpieczeniowych. Główna hipoteza badawcza brzmi: z perspektywy dojrzałego klienta indywidualnego immanentne cechy danego produktu ubezpieczeniowego są bardziej istotne niż czynniki związane z procesami okołosprzedażowymi. Do analizy wymienionych zależności wykorzystano uporządkowany wielopoziomowy model logitowy, w którym rolę zmiennych zależnych pełniły determinanty wyboru produktu ubezpieczeniowego.

Słowa kluczowe: ubezpieczenie, uporządkowany model logitowy, preferencje klientów, decyzje zakupowe. 